\title{
Influence of Aggressivenessand Conservativenessin Investing and Financing Policies on Performance of Industrial Firms in Kenya
}

\author{
Kungu, J. ${ }^{1} *$, Wanjau, K. L. ${ }^{2}$,Waititu, A. G. ${ }^{3}$ \& Gekara, G. M. ${ }^{4}$ \\ 1. Department of Business, Nyandarua Institute of Science and Technology, Nyahururu, Kenya \\ 2. School of Human Resource Development, Jomo Kenyatta University of Agriculture and Technology, \\ Nairobi, Kenya \\ 3. School of Actual Science ,Jomo Kenyatta University of Agriculture and Technology, Nairobi, Kenya \\ 4. School of Business, East African University, Nairobi, Kenya
}

\begin{abstract}
Working capital level determines whether a firm is aggressive or conservative in its operations. Aggressiveness in application of working capital management brings about improved financial performance but at the same time increases the level of risk. The paper looks at the influence of working level on performance in the industrial firms in Kenya.A sample was determined through stratified sampling method in order to include all different types of industries in Kenya. A questionnaire was used to collect data from chief Finance Officers of industrial firms in Kenya. Both descriptive and inferential analyses were done. Analysis of Variance (ANOVA) and regression analysis were used to test the hypothesis. The results show that there is a positive relationship between performance and working capital levels inindustrial firms in Kenya (0.544). Working Capital Levels explain $29.6 \%$ of the performance in the industrial firms in Kenya. $60.4 \%$ of the variation in performance is explained by other factors. The findings of the study revealed that the finance managers are cautious in the use of working capital items. They apply moderate financing and investment strategies.Therefore, we recommend the finance managers to be trained on issues of better utilization of working capital items for improved performance.
\end{abstract}

Key words:(Aggressiveness, Conservativeness, Industrial Firms, Performance, Working Capital Levels)

\section{Introduction}

Working capital is the amount of funds which a company needs to finance its day to day operations (Nkwankwo, \& Osho, 2010). It is the difference between current assets and current liabilities. A company can maintain a high level of its working capital in relation to its total assets or may maintain its working capital at a low level. Whatever the level of working capital maintained by a firm, there is an opportunity cost that is incurred. It may either be liquidity risk or reduced profit. The opportunity cost depends on whether the firm adopts a conservative or aggressive working capital policy.

\subsection{Theoretical Discussion}

Basically, firms apply aggressive, moderate or conservative working capital policies. High risk - high return working capital investment and financing strategies are aggressive strategies while low risks and low return strategies are conservative strategies (Moyer, McGuigar \& Kretlow, 2012; Pinches, 1997; Brigham \& Gapenski, 1994 and Gitman, 2009). Firms may apply four different working capital policies namely aggressive investment policy, conservative investment policy, aggressive financing policy or conservative financing policy.

\subsubsection{Aggressive Investment Policy}

An aggressive investment policy deals with the firm's active control and management of current assets with the aim of minimizing them (Hussain, Farooz \& Khan, 2012). Under this policy current assets are only demanded as they are needed to facilitate the operation of the business. According to Al-Shubiri (2011) aggressive investment policy results in minimal level of investment in current assets versus fixed assets. Aggressive investment policy indicates the smallest level of investment in short term assets versus long term assets (Afza \& Nasir, 2009).

The degree of aggressiveness of working capital investment policy is measured by ratio of current assets to total assets, where the lower value of this ratio shows more aggressiveness (Weinraub \& Visscher, 1998 and Afza \& Nasir, 2009). Other things being the same, an aggressive investment policy results in lower current assets, lower expenses, a shorter cash conversion cycle, higher risk and higher required return to compensate the risk (Pinches, 1997). Hussain, Farooz \& Khan (2012) found that firms that use an aggressive investment policy with low level of current assets increase profitability. 


\subsubsection{Conservative Investment Policy}

Conservative assets management is a passive approach, in which current assets grow in size whatever the situation is (Pinches, 1997). A conservative investment policy sets a greater proportion of funds in short term assets versus long term assets with opportunity cost of low level profit (Afza \& Nasir, 2009). Conservative investment policy places a greater proportion of capital in liquid assets as opposed to productive assets (AlShubiri, 2011). In managing current assets, the policy is more conservative, if the firm uses more current assets in proportion to total assets (Weinraub \& Visscher, 1998). Al-Mwalla (2012) found that a conservative investment policy has a positive impact on a firm's profitability and value.

Raheman, Afza, Qayyum \& Bodla (2010) found that firms follow a conservative working capital policy. However, Weinraub \& Visscher (1998) had found that industries do not significantly follow either aggressive or conservative working capital policies. Therefore, some firms follow aggressive and others conservative working capital policies. There is no strong tendency that a more aggressive approach in one area is balanced by a more conservative approach in the other (Weinraub \& Visscher, 1998). According to (Sathyamoorthi \& Wally Dima, 2008) companies tend to adopt a conservative investment approach during the time of high business volatility and an aggressive investment approach in the time of low volatility.

\subsubsection{Aggressive Financing Policy}

According to Campsey, Brigham, Gilroy \& Hutchinson (1998) and Ikram, Mohammad, Khalid \& Zaheer (2011) current liability is a desirable source of financing because it is usually cheaper than long term liabilities. Aggressive financing policy utilizes higher levels of current liabilities and less long term debt (Afza \& Nasir, 2009 and Al-Shubiri, 2011). Using aggressive financing policy the firm finances its seasonal and possibly some permanent requirements of current assets with current liabilities (Gitman, 2009). Other things remaining the same, the higher the current liabilities, the more aggressive the firm's financing policy and low level of current liability leads to conservative financing policy (Pinches, 1997).

Firms put the liquidity at risk, if they concentrate more on the utilization of current liabilities by using aggressive current liability policy (Afza \& Nasir, 2009). The level of aggressiveness of working capital financing policy is measured by ratio of short term liabilities to total assets, where the higher value of this ratio shows more aggressiveness (Weinraub \&Visscher, 1998) and Afza \& Nasir, 2009). An aggressive financing policy results in higher shorter term liabilities, shorter cash conversion cycle, lower interest cost, higher risk and higher required return (Pinches, 1997). Hussain, Farooz \& Khan, (2012) found that firms that use an aggressive financing policy with high level of current liabilities increase profitability. However, Al-Mwalla (2012) found that an aggressive financing policy has a negative impact on firm's profitability and value.

\subsubsection{Conservative Financing Policy}

A conservative financing policy uses more long term debt and capital. In an aggressive financing policy, a firm uses high levels of short term liabilities and low level of long term debt (Weinraub \& Visscher, 1998). According to (Sathyamoorthi \& Wally - Dima (2008) companies tend to adopt a conservative financing approach during the time of high business volatility and an aggressive financing approach in the time of low volatility. Across the board firms use either an aggressive or conservative financing policy and there is no strong tendency that a more aggressive approach in one area is balanced by a more conservative approach in the other (Weinraub \& Visscher, 1998).

\subsection{Empirical Studies}

Hussain, Farooz \& Khan (2012) investigated the relationship between aggressiveness investment policy and aggressiveness financing policy with profitability in Pakistan manufacturing firms for the period 2006 2010 through correlation and panel data regression analysis using fixed effects models. The results of the study revealed that low investment in current assets and low current liabilities financing increases the profitability of firms. The study also revealed that company size and sales growth positively affect the profitability and leverage ratio has a negative effect while gross domestic product (GDP) growth has no effect on the profitability of manufacturing companies in Pakistan.

Al-Shubiri (2011) investigated the relative relationship between aggressive / conservative working capital policies for 59 industrial companies listed at Amman Stock Exchange for the period 2004-2007. He examined the impact of aggressive and conservative working capital investment and financing policies through cross sectional regression models between working capital policies and profitability as well as the risk of the firms. The results show a negative relationship between profitability measures of firms and the degree of aggressiveness of working capital investment and financing policies. The firms yield negative returns if they follow aggressive working capital policies. 
Ikram, Mohammad, Khalid \& Zaheer (2011) undertook a study to investigate the relationship between working capital management and profitability in the cement industry in Pakistan. The result of their study concludes that there is a moderate relationship between working capital management and profitability in the specific context of cement industry in Pakistan.

Raheman, Afza, Qayyum \& Bodla (2010) analyzed the impact of working capital management on firms' performance in Pakistan for the period 1998 to 2007. They used balanced panel data of 204 manufacturing firms listed in Karachi stock exchange. The results indicated that cash conversion cycle, net trade cycle and inventory turnover in days are significantly affecting the firms. The manufacturing firms were in general facing problems with their collection and payment policies. The study also concluded that firms in Pakistan were following conservative working capital management policy and the firms were needed to concentrate and improve their collection and payment policy.

Sathyamoorthi \& Wally - Dima (2008) analyzed retail domestic companies listed in Botswana stock exchange from 2004 to 2006 and found evidence that companies adopted a conservative approach in working capital management, which suggests that it is not static over time, but varies with the change of macroeconomic factors. In times of high business volatility, companies tend to adopt a conservative approach and tend to adopt an aggressive approach in the times of low volatility.

Weinraub \& Visscher (1998) carried out a study on industry practice relating to aggressive conservative working capital policies for ten diverse industry groups over a 10 years time period. The purpose of the study was to examine the relative relationship between aggressive and conservative working capital practices. The data for the period between 1984 and 1993 was obtained using compustat. The results of the study strongly show that industries had significantly different current assets management policies. The relative industry ranking of the aggressive/conservative asset policies exhibited remarkable stability over time. Industry policies concerning relative aggressive/conservative liability management were also significantly different. It was evident that there was a high and significant negative correlation between industry asset and liability policies. Relatively aggressive working capital asset management seems balanced by relatively conservative working capital financial management.

Since the working capital levels have some influence on performance as per the empirical evidence, the purpose of the study was to assess the influence of working capital levels on performance of industrial firms in Kenya and the hypothesis was stated as follows:

$\mathrm{H}_{01}$ : Working capital levels do not have any significant influence on performance of industrial firms in Kenya

$\mathrm{H}_{11}$ : Working capital levels have a significant influence on performance of industrial firms in Kenya

\section{Methodology}

In the study descriptive research design was used to collect data from chief finance officers of industrial firms in Kenya. The data was collected in Nairobi industrial area. A stratified random sampling technique was used to come up with a sample. A structured self administered questionnaire was used to collect data.

Both reliability and validity tests were carried out. Cronbach's alpha computed was 0.853 which was more than 0.7 and the factor loading of all the questions were between 0.744 and 0.845 which were more than 0.4. These questions were considered for further analysis. Descriptive data analysis was done in form of percentages, mean and standard deviation. This was followed by the inferential statistics in form of Karl Pearson correlation, ANOVA and regression analysis.

\subsection{Descriptive Analysis}

\section{Findings And Discussion}

In this section of the analysis, presentation of the data is in form of tables and narratives. The tables columns for responses in form of percentages for those who strongly disagree (S. D.), disagree (D.), undecided $(\mathrm{U})$, agree (A), strong agree (S. A.) and total percentage amounting to 100.The mean and standard deviation (Std. Dev.) are also included in the table.

Table 1 shows that $69.1 \%$ of the respondents indicated that their firms were maintaining a low level of current assets in relation to total assets while $12.7 \%$ did not commit themselves. $18.2 \%$ claimed that their firms maintained a high level of current assets to the total assets. The question had a mean of 3.51 and a standard deviation of 1.078. Majority of the responses were 4. This is an aggressive investment policy because current assets are kept low and are not allowed to grow in size and have an effect of increasing profitability. 
Table 1: Level of current assets as a percentage of total assets

\begin{tabular}{lllllllll}
\hline Response & S. D. & D. & U. & A. & S. A. & Total & Mean & Std. Dev. \\
Per cent & 9.9 & 8.4 & 12.7 & 59.2 & 9.9 & 100 & 3.51 & 1.078 \\
\hline
\end{tabular}

Table 2 shows that $74.7 \%$ of the respondents indicated that their firms maintained a current ratio of 2:1 which is ideal and $7 \%$ of the respondents did not commit themselves. $18.3 \%$ of the respondents indicated that their firms did not maintain a current ratio of 2:1. The question had a mean of 3.65 and a standard deviation of 0.860 . This shows that firms are able to maintain current ratio at $2: 1$. Therefore, the industrial firms apply moderate financing and investing strategies.

Table 2: Whether the Level of current ratio maintained by the firms is 2:1

\begin{tabular}{|c|c|c|c|c|c|c|c|c|}
\hline Response & S. D. & D. & U. & A. & S. A. & Total & Mean & Std. Dev. \\
\hline Per cent & 7.0 & 11.3 & 7.0 & 59.2 & 15.5 & 100 & 3.65 & 0.860 \\
\hline
\end{tabular}

Table 3 shows that $50.7 \%$ of the respondents indicated that their firms maintained a high ratio of current liabilities in relation to total liabilities, $18.3 \%$ did not commit themselves. $31 \%$ of the respondents indicated that their companies maintained a low ratio between current liabilities to total liabilities. The question had a mean of 3.11 and a standard deviation of 1.151. Most of the responses were 3 . This shows that the respondents were indifference as to whether firms maintained a high or low ratio of current liabilities to total liabilities. This is a sign that the industrial firms apply moderate financing policy in their operations.

Table 3: Relationship between current liabilities and total liabilities

\begin{tabular}{lllllllll}
\hline Response & S. D. & D. & U. & A. & S. A. & Total & Mean & Std. Dev. \\
Per cent & 18.3 & 12.7 & 18.3 & 40.8 & 9.9 & 100 & 3.11 & 1.151 \\
\hline
\end{tabular}

Table 4 shows that $56.3 \%$ of the respondents indicated that their firms were maintaining a high ratio, 11.3\% were indifferent while $32.4 \%$ maintained that their firms maintained a low ratio. The question had a mean of 3.35 and standard deviation of 1.277. Majority of the responses were 3. This shows that the number of respondents agreeing and disagreeing on this view was almost equal. Therefore, with this response moderate financing policy is used by the industrial firms.

Table 4: Relationship between current liabilities and to total assets

\begin{tabular}{lllllllll}
\hline Response & S. D. & D & U. & A. & S. A & Total & Mean & Std. Dev. \\
Per cent & 8.5 & 23.9 & 11.3 & 36.6 & 19.7 & 100 & 3.35 & 1.277 \\
\hline
\end{tabular}

Table 5 shows that $39.5 \%$ of the respondents indicated that the current assets of their firms were financed through long term funds, $11.3 \%$ did not commit themselves while $49.3 \%$ indicated that current assets were financed through current liabilities of their firms. The question had a mean of 2.89 and a standard deviation of 0.762 . This shows that majority of the responses were 3 and the firms apply moderate financing policy.

Table 5: Financing of current assets by the long term funds of the firm

\begin{tabular}{lllllllll}
\hline Response & S. D & D. & U. & A. & S. A & Total & Mean & Std Dev. \\
Per cent & 12.7 & 36.6 & 11.3 & 28.2 & 11.3 & 100 & 2.89 & 0.762 \\
\hline
\end{tabular}

\subsection{Inferential Statistics}

This section looks at the empirical data in three levels; correlation, ANOVA and regression analysis. The correlation analysis shows the relationship between working capital levels and performance in industrial firms in Kenya. The regression analysis gives the model that helps predict performance from working capital levels and also helps in the acceptance or rejection of the hypothesis. The ANOVA is used to determine whether the results are significant.

\subsubsection{Correlation Analysis}

Table 6 indicates that there is a positive significant linear relationship between working capital levels and performance of industrial firms in Kenya. This relationship has been illustrated by correlation coefficient of 0.544 at 0.01 significant levels. This implies that there is a moderate significant positive relationship between working capital levels and performance of industrial firms in Kenya. 
Influence of Aggressiveness and Conservativeness in Investing and Financing Policies on

\section{Table 6: Correlation between Working Capital Levels and Performance}

\begin{tabular}{llcc}
\hline & & Performance & $\begin{array}{c}\text { Working Capital } \\
\text { Levels }\end{array}$ \\
\hline Performance & Pearson Correlation & 1 & \\
& Sig. (2-tailed) & - & \\
\multirow{2}{*}{ Working Capital Levels } & Pearson Correlation & $.544^{* *}$ & 1 \\
& Sig. (2-tailed) & .000 & - \\
\hline
\end{tabular}

**. Correlation is significant at the 0.01 level (2-tailed).

Table 7 provides $R$ and $R^{2}$ value. The $R$ value is 0.544 , which represents the sample correlation. It indicates a moderate correlation between working capital levels and Performance. The $\mathrm{R}^{2}$ value indicates how much of the dependent variable, "Performance" can be explained by the independent variable "Working Capital Levels". In this case, $\mathrm{R}^{2}=29.6 \%$ which can be said to be relatively moderate.

Table 7: Model summary for Working Capital Levels

\begin{tabular}{ccccc}
\hline Model & $\mathrm{R}$ & R Square & Adjusted R Square & Std. Error of the Estimate \\
\hline 1 & $.544^{\mathrm{a}}$ & .296 & .286 & 4.98738
\end{tabular}

a. Predictors: (Constant), Working Capital Levels

\subsubsection{ANOVA Results}

The results in Table 8indicate that the regression model predicts the outcome variable significantly well. This indicates the statistical significance of the regression model that was applied. An F statistic of 29.018 indicated that the model was significant. This was supported by the probability value of 0.000 . This is less than the conventional probability of 0.05 , and indicates that the overall model applied can significantly be applied to predict the outcome variable.

Table 8: ANOVA for Working Capital Levels and Performance

\begin{tabular}{llccccc}
\hline Model & & Sum of Squares & df & Mean Square & F & Sig. \\
\hline & Regression & 721.806 & 1 & 721.806 & 29.018 & $.000^{\mathrm{a}}$ \\
Residual & 1716.305 & 69 & 24.874 & & \\
Total & 2438.111 & 70 & & & \\
\hline
\end{tabular}

a. Predictors: (Constant), Working Capital Levels

b. Dependent Variable: Performance

\subsubsection{Regression Analysis}

Table 9 provides information needed to predict performance from working capital levels. Both the constant and working capital levels contribute significantly to the model. The regression equation is presented as follow; $\mathrm{Y}=6.728+1.217 \mathrm{X}_{5}$

Where $\mathrm{Y}=$ Performance

And $\mathrm{X}_{5}$ is the Working Capital Levels

From table 9, there is a positive unstandardized beta co-efficient of 1.217 as indicated by the co-efficient matrix. Table 9 shows that the p-value is less than 0.05. Therefore, in this case the null hypothesis that working capital levels have a significant influence on performance of industrial firms in Kenya should be accepted.

Table 9: Prediction of Performance from Working Capital Levels

\begin{tabular}{|c|c|c|c|c|c|c|}
\hline \multirow[b]{2}{*}{ Mod } & & \multicolumn{2}{|c|}{ Unstandardized Coefficients } & \multirow{2}{*}{$\begin{array}{c}\text { Standardized } \\
\text { Coefficients }\end{array}$} & \multirow[b]{2}{*}{$\mathrm{t}$} & \multirow[b]{2}{*}{ Sig. } \\
\hline & & $\mathrm{B}$ & Std. Error & & & \\
\hline \multirow[t]{2}{*}{1} & (Constant) & 6.728 & 2.514 & & 2.677 & .009 \\
\hline & Working Capital Levels & 1.217 & .226 & .544 & 5.387 & .000 \\
\hline
\end{tabular}

a. Dependent Variable: Performance 


\section{Conclusion And Recommendation}

Whatever the level of working capital maintained by the firms, there is an opportunity cost that is incurred. It may either be liquidity risk or reduced profit. Neither conservative nor aggressive financing policy was used and this means that there was neither too high nor too low use of long term debt and capital (Pinches, 1997). Since the firms used moderate financing policy, it may be concluded that the business environment was moderately volatile. Firms tend to adopt a conservative financing approach during the time of high business volatility and an aggressive financing policy during the time of low volatility (Sathyamoorthi \& Wally - Dima, 2008). Conservative or aggressive investment approaches were never applied by the firms. This implies that firms' performance level was moderate (Weinraub \& Visscher, 1998).

The results showed that there exists a positive linear relationship between working capital levels and performance for the sampled industrial firms in Kenya. The study accepted the null hypothesis $\left(\mathrm{H}_{1}\right)$ working capital levels have a significant influence on the performance of industrial firms in Kenya.

\section{Suggested Areas Of Further Research}

From the study, it was discovered that the finance managers are very cautions in the use of working capital items. They apply moderate financing and investment policies. The firms should employ finance managers with sound financial knowledge or retrain the finance managers on financial matters to ensure that they understand better utilization of working capital items for the purpose of maximizing profits for their firms. The following are other suggested areas of further research:-

- The scope of the study can be extended to other types of businesses such as retail chain businesses.

- The study was carried out in a developing country. The results of the study can only be applied in the developing countries, more so in Africa. Therefore, similar study can be carried out in the developed nations.

- A more comprehensive study should be carried out on the tripartite influence of working capital levels, liquidity and profitability

\section{Reference}

[1] Afza, T. \& Nasir, M. S. (2009). Is it better to be aggressive or conservative in managing Working Capital? Journal of Quality and Technology Management. Vol. 3 No. 2, pp. 11-21

[2] Al-Mwalla, M. (2012). The Impact of Working Capital Management Policies on Firms Profitability and Value: The case of Jordan. International Research Journal of Finance and Economics, Vol. 85, pp. 147-153

[3] Al-Shubiri, F. N. (2011). Analyzing the Relationship between Working Capital Management Policy and Operating Risk: An Empirical Study on Jordanian Industrial Companies. Hebron University Research Journal, Vol. 6, No. 1, pp. 287-306.

[4] Brigham, E. \& Gapenski, J. (1994). Fundamentals of financial management, New York: Dryden Publishers

[5] Campsey, B.J., Brigham, E. F., Gilroy, N. \& Hutchinson, P.J. (1994). Introduction to Financial Management,Sydney: Hrcourt Brace and Company

[6] Gitman, L. A. (2009). Principles of Managerial Finance, New York: Addison Wesley Publishers

[7] Hussain, A., Farooz, S. U. \& Khan, K.U. (2012). Aggressiveness and Conservativeness of Working Capital: A case of Pakistan Manufacturing Sector, European Journal of Scientific Research, Vol. 73, No. 2, pp. 171-182

[8] Ikram, H., Mohammad, S., Khalid, Z. \& Zaheer, A. (2011). The relationship between Working Capital Management and Profitability: A Case study of Cement Industry in Pakistan, Mediterranean Journal of Social Sciences, Vol. 2 No. 2, pp. 63-74

[9] Moyer, McGuigar \& Kretlow (2002). Contemporary Financial Management, New York: West Publishing,

[10] Nkwankwo, O. \& Osho, G.S. (2010). An Empirical Analysis of Corporate Survival and Growth: Evidence from Efficient Working Capital Management, International Journal of scholarly Academic Intellectual Diversity, Vol. 12 No. 1, pp. 1-13.

[11] Pinches, G (1997). Essentials of financial management, New York: Harper Collis Publishing

[12] Raheman, Afza, Qayyum \& Bodla, Working Capital Management and Corporate Performance of Manufacturing Sector Pakistan, International Research Journal of Finance and Economics, Issue 47, 2010

[13] Sathyamoorthi, C. R. \& Wally - Dima, L. B. (2008). "Working Capital Management: The case of listed Rental Domestic Companies in Botswana". The ICFAIAN Journal of Management Research, Vol. VII, Issue 5, pp. 7-24 [14] Weinraub, H. J. \& Visscher, S. (1998). Industry Practice relating to Aggressive / Conservative Working Capital Policies, Journal of Financial and Strategic decisions, Vol. 11, No. 2, pp. 11-18 